УДК 657

DOI: https://doi.org/10.32782/2520-2200/2020-2-17

Височан О.С.
доктор економічних наук,
профресор кафедри обліку та аналізу
Національного університету "Львівська політехніка"

Оліховський В.Я.

кандидат економічних наук, асистент кафедри обліку та аналізу Національного університету «Львівська політехніка»

Vysochan Oleh, Olikhovskiy Volodymyr Lviv Polytechnic National University

\title{
ORGANIZATION OF ACCOUNTING OF TOURIST SERVICES IN LOW-COST SEGMENT
}

\begin{abstract}
У статті встановлено ознаки, характерні для діяльності підприємств лоукост-сегменту туристичного бізнесу, що чинять найбільший вплив на побудову системи бухгалтерського обліку. Доведено актуальність вибраної тематики, керуючись показниками темпів зростання туристичної галузі у світі, що неминуче впливає на економічний розвиток країн, зайнятість населення, охорону навколишнього середовища та збереження культурної спадщини. Наведено основні принципи, на яких ґрунтується діяльність компаній лоукост-сегменту туристичного бізнесу. Представлено риси, притаманні обліку лоукост-компаній, провоковані масштабністю їхньої діяльності, яка супроводжується рутинністю і типовістю господарських операцій. Узагальнено пріоритетні та найбільш трудозатратні ділянки, які вимагають максимальної уваги під час організації облікового процесу. Узагальнено вплив характеристик послуг/турпродукту, які надаються компаніями, що сповідують концепцію «лоу-кост», на систему бухгалтерського обліку.
\end{abstract}

Ключові слова: бухгалтерський облік, туристична послуга, туризм, організація обліку, лоукостперевізник, перевізник із повним сервісом.

В статье установлены признаки, характерные для деятельности предприятий лоукост-сегмента туристического бизнеса, оказывающие наибольшее влияние на построение системы бухгалтерского учета. Доказана актуальность тематики, руководствуясь показателями темпов роста туристической отрасли в мире, что неизбежно влияет на экономическое развитие стран, занятость населения, охрану окружающей среды и сохранения культурного наследия. Приведены основные принципы, на которых основывается деятельность компаний лоукост-сегмента туристического бизнеса. Представлены черты, присущие учету в лоукост-компаниях, провоцируемые масштабностью их деятельности, сопровождающиеся рутинностью и типичностью хозяйственных операций. Обобщены приоритетные и наиболее трудозатратные участки, требующие максимального внимания при организации учетного процесса. Обобщено влияние характеристик услуг/турпродукта, предоставляемых компаниями, исповедующими концепцию «лоу-кост», на систему бухгалтерского учета.

Ключевые слова: бухгалтерский учет, туристическая услуга, туризм, организация учета, лоукост-перевозчик, перевозчик с полным сервисом.

The article identifies features that are characteristic of the activity of low-cost enterprises of the tourist business segment, which have the greatest impact on the construction of the accounting system. Among them: cost minimization - low-cost companies seek to reduce costs by using all legal means; scale of activity - profitability in low cost companies is achieved not by a high margin (as the difference between the cost of sales and cost), but by the large volume of services provided and their maximum concentration; active sale of related and ancillary services, in particular: car rental, insurance sales, gift vouchers, organization of additional meals above the basic tourist service, tickets for entertaining 
events, ordering guide services, information and consulting services and a number of others. The topicality of the chosen topic is proved, taking into account the growth rates of the tourist industry in the world, which inevitably affects the economic development of the countries, employment of the population, environmental protection and preservation of cultural heritage. It was found that the market share of low-cost carriers increased from $15.7 \%$ in 2006 to 31\% in 2018; Ryanair's low-cost carrier has become Europe's largest airline with 152.4 million passengers. The basic principles on which the activity of the low-cost companies of the tourist business segment are based. The features inherent in the accounting of low-cost companies are presented, provoked by the scale of their activity, which is accompanied by the routine and typicality of business operations. The priority and the most labor-intensive areas are summarized, which require maximum attention when organizing the accounting process. The influence of the characteristics of services / tourist products provided by low cost companies on the accounting system is generalized: improvement of the method of accounting of discounts taking into account the accepted price policy; the need to build accounting (including analytical), taking into account the division of activities into main, additional and related; creating reserves to synchronize and offset costs and revenue over the reporting period.

Key words: accounting, tourist service, tourism, accounting organization, low-cost carrier, full-service carrier.

Постановка проблеми. Упродовж останнього десятиліття індустрія туризму демонструє стабільні темпи зростання, що неминуче впливає на економічний розвиток країн, зайнятість населення, охорону навколишнього середовища та збереження культурної спадщини. Значна кількість країн (Чорногорія, Хорватія, Мальта, Таїланд, Мальдіви тощо) понад 10\% ВВП отримують від туризму. Фактично це означає, що добробут населення цих країн напряму залежить від розвитку туристичної галузі.

Поступова переорієнтація ринкового механізму розвитку туризму на умови, що потребують урахування попиту різних споживачів та узгодження $з$ ними пропозиції, призвела до ситуації, коли існуюча облікова система не здатна надати необхідні відомості для достовірної оцінки ефективності туристичної діяльності підприємства [1, с. 219].

Саме необхідність задоволення попиту клієнтів у послугах, що надаються за мінімальною вартістю без утрати якості останніх, призвела до появи лоукост-сегменту туристичного бізнесу.

Аналіз останніх досліджень і публікацій. Облік у туризмі знаходиться у фокусі досліджень таких вітчизняних учених, як: Р.І. Балашова, З.А. Балченко, Ж.А. Богданова, О.М. Гончаренко, Т.П. Данканич, В.М. Жук, С.Я. Король, Т.В. Момонт, Т.С. Осадча, С.М. Пилипенко, І.М. Пожарицька, О.В. Прокопишина, Н.Б. Рошко, О.В. Сметанко та ін. Водночас особливості облікових процесів, притаманних лоукост-моделі ведення бізнесу, досі залишаються малодослідженими.

Метою дослідження $€$ встановлення ознак, характерних для діяльності підприємств лоукост-сегменту туристичного бізнесу, що чинять найбільший вплив на побудову системи бухгалтерського обліку останніх.
Завдання дослідження:

1) навести основні принципи, на яких грунтується діяльність компаній лоукост-сегменту туристичного бізнесу;

2) представити риси, притаманні обліку лоукост-компаній, провоковані масштабністю їхньої діяльності, яка супроводжується рутинністю і типовістю господарських операцій;

3) узагальнити пріоритетні та найбільш трудозатратні ділянки, які вимагають максимальної уваги під час організації облікового процесу;

4) узагальнити вплив характеристик послуг/ турпродукту, які надаються компаніями, що сповідують концепцію "лоу-кост», на систему бухгалтерського обліку.

Виклад основного матеріалу дослідження. Концепція діяльності на засадах лоу-кост сьогодні асоціюється зі сферою перевезень пасажирів, у якій вона набула найбільшої популярності.

Інформація, оприлюднена ресурсом statista. com [2], свідчить про те, що частка ринку лоукост-перевізників зросла з 15,7\% у 2006 р. до $31 \%$ у 2018 р. (майже вдвічі!). Тому не дивує той фракт, що, за даними Skycop, у 2019 р. лоукостер Ryanair став найбільшою авіакомпанією Європи за кількістю перевезених пасажирів - 152,4 млн осіб [3]. Ця ж компанія разом зі ще одним лоукостером easyJet, за даними Business Insider [4], увійшла до 10 найбільших авіакомпаній світу, випереджаючи таких гігантів, як Аэрофрлот, Air France, Emirates, Lufthansa та Turkish Airlines.

У зарубіжній літературі лоукост-перевізники (Low-cost Carriers - LCC) протиставляються перевізникам із повним сервісом (Fullservice Carriers - FSC). Перші завдяки оптимізації різноманітних операційних процесів отримують цінові переваги над другими. Як наслідок, це дає їм змогу пропонувати клієнтам послуги за нижчими, ніж у FSC-компаній, тарифами. 
Філіп Детлін із Массачусетського технологічного інституту серед ознак, притаманних лоукост-моделі в авіаперевезеннях називає такі: перельоти на короткі відстані; використання вторинних та/або незавантажених аеропортів; незначні обсяги транзитних пасажирів; високий рівень завантаженості маршрутів; розповсюдження квитків власними каналами, наприклад через кол-центри або модулі з продажу квитків на Інтернет-сайті компанії; один клас подорожі з відносно високою щільністю сидінь; проста структура фолоту, зазвичай із використанням лише одного типу літака; щоденна експлуатація літаків; гнучкі правила роботи; уникнення участі у глобальних альянсах та деякі інші [5].

Основною метою фрінансово-господарської діяльності туристичних підприємств $€$ не лише отримання прибутку, а й створення якісного продукту, який максимально задовольнятиме вимогам споживачів. Баланс між цими часто взаємовиключаючими цілями й $є$ основним завданням для менеджменту туристичних підприємств, інфоормаційну підтримку вирішення якого повинна забезпечити підсистема бухгалтерського обліку [6, с. 132].

Основними принципами, на яких ґрунтується діяльність компаній лоукост-сегменту туристичного бізнесу (не лише у секторі авіаперевезень), що впливають на організацію облікового процесу, на нашу думку, є:

1) мінімізація собівартості. Компанії-лоукостери прагнуть знизити ціну, використовуючи всі легальні засоби. Наслідками можуть бути:

- зарплати персоналу лоукостерів зазвичай нижчі середньогалузевих показників, тоді як інтенсивність роботи - вища;

- фрагментація туристичної послуги, з окремих компонент якої формуються додаткові послуги, які оплачуються понад вартість основної;

- перенесення значної частини активностей фрронт-офрісу (довідка, продаж квитків, повернення платежів, прийом рекламацій, зв'язок зі службою технічної підтримки тощо) в онлайнформат (у т. ч. і за рахунок активного використання у діяльності мобільних додатків, систем електронної комерції, чату, електронних кабінетів клієнта тощо), що забезпечує зменшення кількості персоналу та обсягів офрісних площ;

- транспортні компанії часто не користуються платформами автостанцій на проміжних зупинках за маршрутом, таким чином, мінімізуючи витрати на оплату послуг, пов'язаних з організацією прибуття і відправлення автобусів;

- авіакомпанії за наявності поблизу великих міст декількох аеропортів вибирають той, який пропонує більш лояльну цінову політику, ігноруючи чинник відстані від місця прибуття (наприклад, аеропорт Хан, який $є$ базовим для декількох бюджетних авіаліній, знаходиться за 120 км від Франкфурта, тоді як основний - лише за 12 км; аеропорт Скавста - за 100 км від Стокгольму, Арланда - 42 км; Саннефріорд - 110 км від Осло, Гардермуен - 45 км від норвезької столиці тощо). Таким чином, частка витрат на подорож до місця призначення фрактично перекладається на споживача;

- інше;

2) масштабність діяльності. Прибутковість у компаніях, які сповідують концепцію «лоу-кост», досягається не за рахунок високої маржі (як різниці міжціною реалізації і собівартістю), а завдяки значним обсягам реалізованих послуг та їх максимальній концентрації, яка характеризується величинами заповнюваності транспортного засобу, повноти посадки в закладі громадського харчування, заселеності готелю тощо. У зв'язку із цим максимальна увага приділяється залученню клієнтів засобами агресивної реклами, широкого використання можливостей Інтернетмережі, постійного проведення акційних розпродажів та ін. Найбільш часто використовується бізнес-модель прямих продажів, оскільки невелика прибутковість кожної окремої послуги стає перепоною для організації дистрибуційної посередницької мережі. Масштабність діяльності дає змогу таким компаніям вибирати агресивну політику співпраці з партнерами, диктуючи умови договорів на власну користь. Наприклад, екскурсоводи, які працюють із туристичними операторами, часто отримують винагороду (в розрахунку на одного туриста) меншу, ніж за умов прямих контактів із клієнтом, однак ці втрати можуть бути компенсованими більшою кількістю замовлень. Водночас масштабність фрактично унеможливлює індивідуальний підхід до клієнта та зумовлює необхідність використання багатьох внутрішніх стандартів, інструкцій та нормативів, які повністю формалізують послідовність дій для розв'язання тих чи інших проблем.

Масштабність діяльності, яка супроводжується рутинністю і типовістю господарських операцій, виводить на перший план питання автоматизації бухгалтерського обліку та його інтеграцію в автоматизовану систему управління лоукост-компанії. Складовою частиною цієї системи є надійний модуль онлайн-платежів, а також ціноутворення. Дані з нього повинні оперативно оброблятися і передаватися для відображення на бухгалтерських рахунках. $€$ можливість виникнення так званого "кумулятивного ефекту», за якого вчасно невиявлена похибка, маючи локальний характер, однак накопичуючись упродовж тривалого часу, може призводити до згубних наслідків для всієї системи бухгалтерського обліку. Не в останню чергу якість облікової інформації в такого роду компаніях визначається її оперативністю. 
Масштабність діяльності та складність організаційних зв'язків призводять до необхідності розроблення певною мірою унікальної системи обліку для таких компаній, обмеженості у використанні типових рішень, унікальності облікової політики, яка повинна максимально повно відповідати на запити управління, а також чіткої маршрутизації інфоормаційно-облікових потоків. Захист персональних даних клієнтів від несанкціонованого доступу також $€$ надважливим завданням;

3) активний продаж супутніх та додаткових послуг. Такими послугами можуть бути: оренда автомобілів, продаж страхових полісів, подарункових ваучерів, організація додаткового харчування понад встановлене у базовій туристичній послузі, реалізація квитків на розважальні заходи, замовлення послуг екскурсовода, інформаційно-консультаційні послуги та низка інших. У такому разі компанія-лоукостер виступає як посередник і отримує додатковий дохід у вигляді агентської винагороди. Лоукостери досить часто йдуть на зниження ціни туристичної послуги до рівня собівартості (а інколи й нижче), сподіваючись на компенсацію втрат за рахунок продажу додаткових та супутніх послуг. Наприклад, авіакомпанія може суттєво знизити вартість квитка в розрахунку на те, що пасажир замовить послугу перевезення додаткового багажу, пріоритетну посадку чи харчування на борту. Окрім того, забезпечується збільшення кількості лояльних до компанії клієнтів, позитивне відношення яких дасть змогу залучити нових покупців у майбутньому.

Облік повинен вестися з обов'язковим розмежуванням основної діяльності та надання супутніх і додаткових послуг. На верхніх рівнях ієрархії синтетичних та аналітичних рахунків узагальнюється інформація щодо доходів i витрат у розрізі видів діяльності та центрів відповідальності. За умов стабільної важливості функціональної прив'язки останніх географічний (територіальний) розподіл за значної частки бізнес-процесів, перенесених в Інтернет-мережу, для таких компаній відходить у минуле.

Пріоритетними та найбільш трудозатратними ділянками, які вимагають максимальної уваги під час організації облікового процесу, є: облік доходів та витрат; облік розрахункових операцій; облік праці та її оплати; облік основних засобів.

Висновки з проведеного дослідження. Організація та методика ведення обліку в компаніях лоукост-сегменту туристичного бізнесу характеризуються такими базовими особливостями:

- значна залежність потенційних клієнтів компаній-лоукостерів від коливань ціни (еластичність попиту свідчить про високу його кореляцію з рівнем доходів населення) зумовлює необхідність використання стратегій, пов'язаних з її мінімізацією, що спричиняє потребу в удосконаленні методики обліку знижок з урахуванням прийнятої цінової політики;

- взаємодоповнюваність послуг у складі продукту, що пропонується лоукостерами, зумовлює необхідність побудови обліку (у т. ч. аналітичного) з урахуванням поділу діяльності на основну, додаткову та супутню;

- можливе коливання попиту у часовому розрізі (наявність сезонного складника) виводить на перший план створення резервів для синхронізації й вирівнювання витрат і доходів упродовж звітного періоду.

\section{Список використаних джерел:}

1. Височан О.С. Витрати на фрормування споживчої цінності туристичного продукту як об'єкт бухгалтерського обліку. Науковий вісник Мукачівського державного університету. Серія "Економіка». 2015. Вип. 2(4). Ч. 1. С. 218-223.

2. Low cost carriers' worldwide market share from 2007 to 2018. URL: https://www.statista.com/ statistics/586677/global-low-cost-carrier-market-capacity-share/ (дата звернення: 25.03.2020).

3. 10 Largest Airlines in Europe by Passenger Numbers. URL: https://www.skycop.com/aviation/ 10-largest-airlines-in-europe-by-passenger-numbers/ (дата звернення: 25.03.2020).

4. Zhang B. The 20 Biggest Airlines in the World, Ranked. URL: https://www.businessinsider.com/ biggest-airlines-world-oag-2019-3 (дата звернення: 25.03.2020).

5. Dietlin Ph. (2004). The Potential for Low-Cost Airlines in Asia. URL: https://dspace.mit.edu/ handle/1721.1/28301 (дата звернення: 25.03.2020).

6. Височан О.С. Концептуалізація розвитку бухгалтерського обліку у суб'єктів, що здійснюють туристичну діяльність : монографрія. Львів : Видавництво Тараса Сороки, 2015. 312 с.

\section{References:}

1. Vysochan O.S. (2015) Vytraty na formuvannia spozhyvchoi tsinnosti turystychnoho produktu yak obiekt bukhhalterskoho obliku [Costs of shaping the consumer value of a tourism product as an accounting object]. Naukovyi visnyk Mukachivskoho derzhavnoho universytetu. Seriia Ekonomika. 2(4). 218-223. 
2. Low cost carriers' worldwide market share from 2007 to 2018 . Retrieved from: https://www.statista.com/ statistics/586677/global-low-cost-carrier-market-capacity-share/ (accessed 25 March 2020).

3. 10 Largest Airlines in Europe by Passenger Numbers. Retrieved from: https://www.skycop.com/ aviation/10-largest-airlines-in-europe-by-passenger-numbers/ (accessed 25 March 2020).

4. Zhang B. The 20 Biggest Airlines in the World, Ranked. Retrieved from: https://www.businessinsider.com/biggest-airlines-world-oag-2019-3 (accessed 25 March 2020).

5. Dietlin Ph. (2004) The Potential for Low-Cost Airlines in Asia. Retrieved from: https://dspace.mit.edu/ handle/1721.1/28301 (accessed 25 March 2020).

6. Vysochan O.S. (2015) Konceptualizacija rozvytku bukhghaltersjkogho obliku u sub'jektiv, shho zdijsnjujutj turystychnu dijaljnistj [Conceptualization of accounting development in entities engaged in tourism]: monoghrafija. Ljviv: Vydavnyctvo Tarasa Soroky. (in Ukrainian) 